\title{
First record of the soybean stem fly Melanagromyza sojae (Diptera: Agromyzidae) in the Brazilian Savannah ${ }^{1}$
}

\author{
Cecília Czepak ${ }^{2}$, Matheus Le Senechal Nunes², Tiago Carvalhais², Marcos Vinicius dos Anjos², \\ Rafael Ferreira Silverio ${ }^{2}$, Paula Barcelos Simões de Oliveira Lima ${ }^{2}$, Karina Cordeiro Albernaz Godinhoº \\ Abmael Monteiro de Lima Junior ${ }^{3}$, Regina Melo Sartori Coelho ${ }^{3}$, Pablo da Costa Gontijo ${ }^{2}$
}

\section{ABSTRACT}

The soybean stem fly [Melanagromyza sojae (Diptera: Agromyzidae)] is a pest widely distributed in the Asian continent. In Brazil, its occurrence has been reported since the 1980s, but it had not been reported in Brazilian Savannah areas yet. This is the first record of M. sojae in this region of great importance for the soybean world production. Specimens of the soybean stem fly were collected in a volunteer soybean area, in April 2018, in the Goiás state, Brazil, and sent for molecular identification. The similarity index of the collected specimens with $M$. sojae was higher than $99 \%$, thus confirming the identification of the species. The infestation level in the collection area was approximately $100 \%$ of plants with damage caused by this insect. In Brazil, the occurrence of M. sojae, up to the present time, had been described as restricted to the southern states. This record raises the hypothesis that $M$. sojae is widespread in other agricultural areas of the Brazilian Savannah, and that its dissemination is favored by the maintenance of volunteer soybean.

KEYWORDS: Glycine max; soybean pests; integrated pest management; volunteer soybean.

The soybean stem fly [Melanagromyza sojae (Diptera: Agromyzidae)] is widely distributed in Asia (Wang \& Gai 2001, Tapha 2012), as well as in parts of Russia (Strakhova et al. 2013), Australia (Shepard et al. 1983, Brier \& Charleston 2013) and Spain (Gil-Ortiz et al. 2010), causing damage to soybean crops (Talekar 1989, Wang \& Gai 2001). Its presence was also recently confirmed in Paraguay (Guedes et al. 2017). In Brazil, its occurrence has been reported since the 1980s, in the southern states of Rio Grande do Sul, Santa Catarina and Paraná (Gassen \& Schneider 1985, Link et al. 2009), and

\section{RESUMO}

Primeiro registro da mosca-da-haste da soja Melanagromyza sojae (Diptera: Agromyzidae) no Cerrado brasileiro

Amosca-da-haste da soja [Melanagromyza sojae (Diptera: Agromyzidae)] é uma praga com ampla distribuição no continente asiático. No Brasil, sua ocorrência tem sido relatada desde a década de 1980; porém, ainda não havia sido encontrada em áreas do Cerrado. Este é o primeiro relato de ocorrência de $M$. sojae nesta região de grande importância para a produção mundial de soja. Espécimes da mosca-da-haste foram coletados em área de soja voluntária, em abril de 2018, no estado de Goiás, e encaminhados para identificação molecular. O índice de similaridade dos espécimes coletados com $M$. sojae foi superior a $99 \%$, confirmando a identificação da espécie. O nível de infestação na área de coleta foi de aproximadamente $100 \%$ de plantas com danos causados pelo inseto. No Brasil, a ocorrência de $M$. sojae, até o presente momento, era descrita como restrita aos estados do sul. Este registro suscita a hipótese de que $M$. sojae esteja disseminada em outras áreas agrícolas do Cerrado brasileiro, e que sua disseminação seja favorecida pela manutenção de plantas de soja voluntária.

PALAVRAS-CHAVE: Glycine max; pragas da soja; manejo integrado de pragas; soja voluntária.

it is considered a biosafety hazard for the country (Hirose \& Moscardi 2012). The presence of M. sojae in Brazil was reported again in secondcrop soybean, in the states of Santa Catarina and Rio Grande do Sul (Guedes et al. 2006, Arnemann et al. 2016), in 2015. However, its occurrence in the Brazilian Savannah had not been reported yet.

In this study, the first occurrence of M. sojae in the Brazilian Savannah was verified by the Laboratory of Integrated Pest Management team of the Escola de Agronomia, Universidade Federal de Goiás (MIP-UFG), at the end of April 2018, in Silvânia

1. Manuscript received in May/2018 and accepted for publication in Jun./2018 (http://dx.doi.org/10.1590/1983-40632018v4853158).

2. Universidade Federal de Goiás, Escola de Agronomia, Goiânia, GO, Brasil.E-mails: ceciczepak@yahoo.com.br, matheuslsn@hotmail.com, carvalhais.tiago@gmail.com, viniciusdosanjos2009@hotmail.com, rafaelsilverio18@hotmail.com, paulabsol.agro@gmail.com, kcalbernaz@gmail.com, pablocgontijo@gmail.com.

3. Ministério da Agricultura, Pecuária e Abastecimento, Goiânia, GO, Brasil.E-mails: abmael.lima@agricultura.gov.br, regina.sartori@agricultura.gov.br. 
(16²6’6,33”S; 4850’4,22”W), Goiás state, Brazil, in an area of 223 ha with volunteer soybean (tiguera, in Portuguese), in the reproductive phase. To estimate the infestation level in the area, ten samples, from ten plants each, were randomly collected. Approximately $100 \%$ of the plants in the area showed damage from M. sojae (Figure 1). Longitudinal cuts of the infested plants allowed to verify the presence of larvae and pupae. The rotting tissues of the soybean stem had a soft consistency and reddish-brown color.

In May 2018, volunteer soybean plants infested by $M$. sojae were collected in the reported area, in the

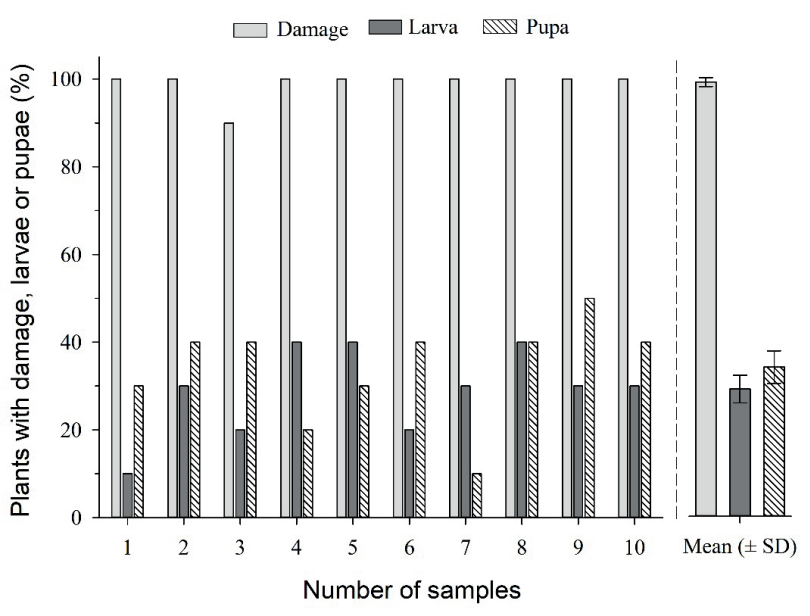

Figure 1. Infestation of the soybean stem fly Melanagromyza sojae, in area of volunteer soybean, in Silvânia, Goiás state, Brazil (April 2018). presence of technicians from the Agência Goiana de Agrodefesa (Agrodefesa) (Collection term ${ }^{\circ} 22323$, series A). Samples collected during the inspections were sent to the laboratory (MIP-UFG), in Goiânia, where the material was screened and M. sojae larvae were transferred to eppendorfs $(1.0 \mathrm{~mL})$ containing alcohol (99\%). Part of the collected material (six larvae and pupae) was identified and deposited in a collection maintained by the same laboratory, and another part was kept in a freezer $\left(-18^{\circ} \mathrm{C}\right)$. Later, the material was sent to the Laboratório Nacional Agropecuário de Goiás (Lanagro-GO/MAPA, Goiânia, Goiás), where the molecular characterization of the $M$. sojae larvae samples was carried out by amplifying the sequence of the cytochrome $\mathrm{C}$ oxidase gene. The DNA extraction from the larvae (three samples) was performed with the DNeasy Blood and Tissue Kit (Qiagen) and amplifications were performed with primer pairs: LCO 1490 (5'-GGTCAACAAATCATAAAGATATTGG-3') and HCO 2198 (5'-TAAACTTCAGGGTGACCAAAAAATCA-3'), at 0.2 uM (Folmer et al. 1994). The PCR for the primer pairs was performed on the Veriti 96well thermal cycler (Life Technologies of Brazil), programmed for 1 cycle of $95{ }^{\circ} \mathrm{C}$ for $15 \mathrm{~min} ; 35$ cycles of $94^{\circ} \mathrm{C}$ for 30 seconds; $51^{\circ} \mathrm{C}$ for $1 \mathrm{~min}$; and $72{ }^{\circ} \mathrm{C}$ for $1 \mathrm{~min}$, with a final extension of $72^{\circ} \mathrm{C}$ for $10 \mathrm{~min}$. The PCR product was purified by enzymatic reaction with the ExoSAP kit (USB Corporation). Sequencing was performed with the ABI Prism 3500
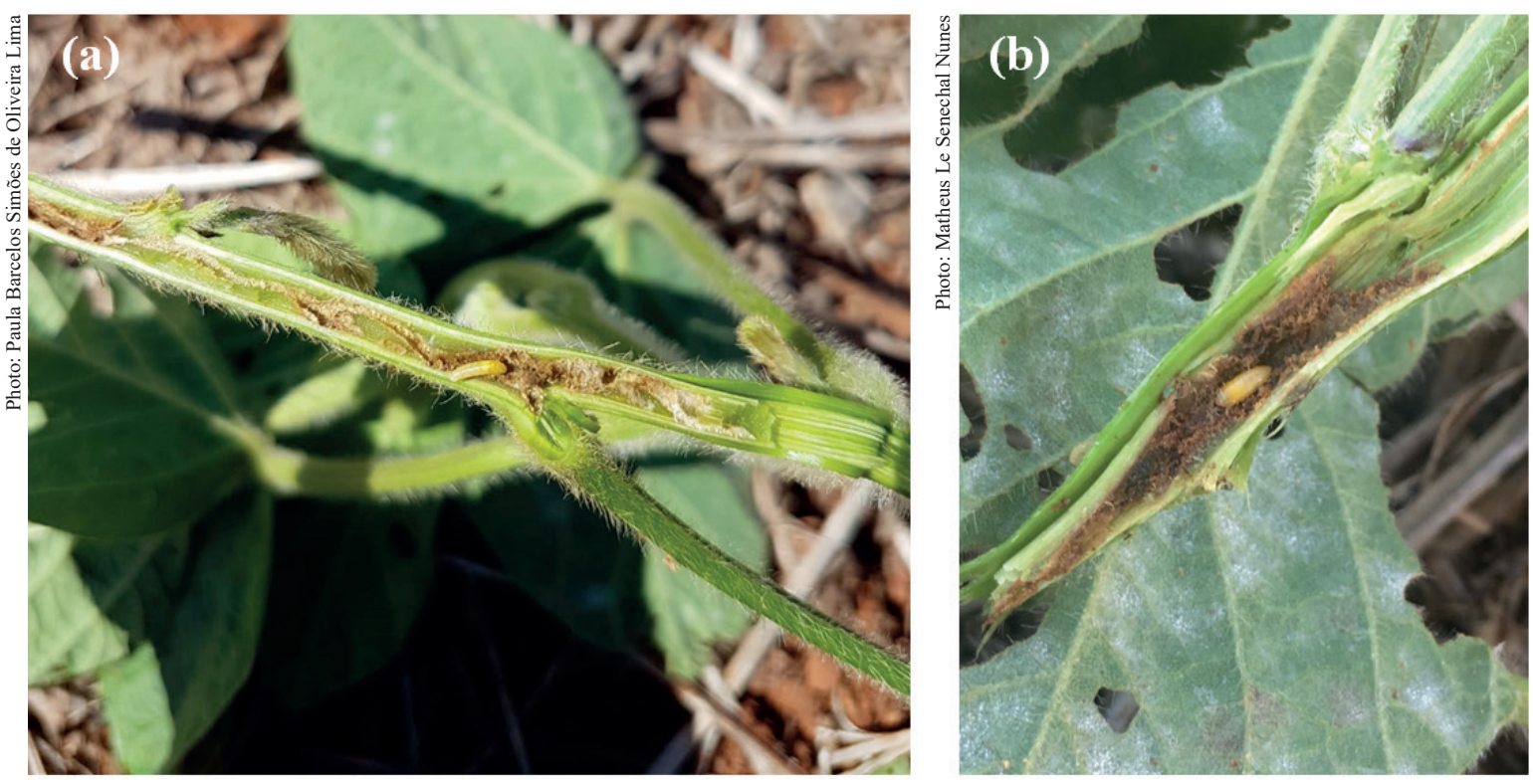

Figure 2. Larva (a) and pupa (b) of the Melanagromyza sojae stem fly in volunteer soybean, in area of the Brazilian Savannah (April 2018). 
DNA Analyzer (Life Technologies of Brazil). Each sequence generated in the AB1 file by the genetic analyzer was saved in a useful comparison unit (FASTA) to search in an authenticated standard database. The acceptance criterion adopted was to obtain a bidirectional sequence of the expected length (at least $500 \mathrm{bp}$ in length), with less than $2 \%$ ambiguous bases in contig sequence, or a single reading with at least $98 \%$ of high quality bases. Post-sequencing analyzes were performed using the Sequencing Analysis Software 6 (Applied Biosystems). The treated sequences were compared with the validated sequences deposited in Bold Systems (Ratnasingham \& Hebert 2007). The similarity index found with the $M$. sojae species was higher than $99 \%$, what confirms the identification of the species.

The soybean stem fly (M. sojae) prefers to infest plants from the Fabaceae family, such as soybean (Hirose \& Moscardi 2012). The small black adult flies $(2-3 \mathrm{~mm})$ are rarely observed in the field, but, in large infestations, they may be seen in inflorescences and foliage. Their endophytic oviposition is performed on the abaxial face of the new leaves, with the eggs inserted into the plant tissues (Brier \& Charleston 2013). After 2 to 3 days, the larvae that initiate the infestation begin to hatch, burrowing the nearest vein and then advancing through the petiole to the stem, forming galleries in parts or their entire extension. The larval period is 7-11 days. After this period, the pupae are formed within the galleries in the plant stems, lasting about 10 days. The complete life cycle varies from 16 to 26 days (Hirose \& Moscardi 2012).

Stem fly infestation can reduce the stem diameter, plant height and distance from internodes, and a thickening at the base of the stem may be observed, which results in dwarfism or nutrient deficiency. In the reproductive phase, the number of pods is reduced. In addition, later planted soybeans infested by $M$. sojae may reach up to $21 \%$ reduced grain yield (Gassen \& Schneider 1985). In India, the high-intensity infestation of $M$. sojae has caused more than $80 \%$ of losses in the soybean production (Plantwise 2015). To control the soybean stem fly infestation, crop rotation, adequate soil preparation and avoidance of late planting are the most effective control practices (Hirose \& Moscardi 2012). Research on the management of this insect with insecticides is also under development (Curioletti et al. 2018).
After the identification of $M$. sojae was confirmed and its occurrence reported in the Brazilian Savannah to the proper inspecting agencies at Agrodefesa, they intensified the inspection in voluntary soybean areas and verified other plants infested by $M$. sojae within $20 \mathrm{~km}$ from the original site. M. sojae may be widespread in other agricultural areas of the Brazilian Savannah, and voluntary soybean plants originating from the remaining grains after harvest have facilitate the maintenance and dispersion of this pest. Inspection in areas with voluntary soybean is necessary, because the destruction of these plants may reduce the incidence of $M$. sojae, or even prevent the pest from spreading to other regions of the state or country. These measures are necessary to avoid M. sojae becoming established in high population levels and causing greater damages to the next soybean crops.

\section{ACKNOWLEDGMENTS}

To the Agrodefesa inspectors, who accompanied the whole process of inspection and collection of the insect after the detection of the infested area, and Fundação de Amparo à Pesquisa do Estado de Goiás (FAPEG), which contributed financially to the maintenance of the monitoring in the agricultural areas, thus enabling important discoveries to be made in the Brazilian agriculture.

\section{REFERENCES}

ARNEMANN, J. A. et al. Complete mitochondrial genome of the soybean stem fly Melanagromyza sojae (Diptera: Agromyzidae). Mitochondrial DNA Part A DNA Mapping, Sequencing, and Analysis, v. 27, n. 6, p. 4534-4535, 2016.

BRIER, H.; CHARLESTON, K. Soybean stem fly outbreak in soybean crops: the beatsheet. 2013. Available at: $<$ https://thebeatsheet.com.au/soybean-stem-fly-outbreakin-soybean-crops/>. Access on: 18 May 2018.

CURIOLETTI, L. E. et al. First insights of soybean stem fly (SSF) Melanagromyza sojae control in South America. Australian Journal of Crop Science, v. 12, n. 5, p. 841848, 2018.

FOLMER, O. et al. DNA primers for amplification of mitochondrial cytochrome $c$ oxidase subunit I from diverse metazoan invertebrates. Molecular Marine Biotechnology, v. 3, n. 5, p. 294-299, 1994. 
GASSEN, D. K.; SCHNEIDER, S. Ocorrência de Melanagromyza sp. (Dip. Agromizidae) danificando soja no sul do Brasil. In: REUNIÃO DE PESQUISA DA SOJA DA REGIÃO SUL, 13., 1985, Porto Alegre. Soja: resultados de pesquisa 1984-85. Passo Fundo: EmbrapaCNPT, 1985. p. 108-109.

GIL-ORTIZ, R. et al. First record of Melanagromyza sojae (Zehnter) (Diptera: Agromyzidae) in Europe. Journal of Entomological Science, v. 45, n. 2, p. 190-192, 2010.

GUEDES, J. V. C. et al. First record of soybean stem fly Melanagromyza sojae (Diptera: Agromyzidae) in Paraguay confirmed by molecular evidence. Genetics and Molecular Research, v. 16, n. 3, p. gmr16039707, 2017.

GUEDES, J. V. C. et al. Mosca-da-haste da soja no Brasil. Cultivar Grandes Culturas, v. 16, n. 197, p. 28-30, 2015.

HIROSE, E.; MOSCARDI, F. Insetos de outras regiões do mundo. In: EMBRAPA. Manejo integrado de insetos e outros artrópodes-praga. Brasília, DF: Embrapa Soja, 2012. p. 445-492.

LINK, D. et al. Mosca da haste da soja: ocorrência e danos. In: REUNIÃO DE PESQUISA DE SOJA DA REGIÃO SUL, 37., 2009, Porto Alegre. Programa e resumos. Porto Alegre: UFRGS, 2009. p. 135-137.
PLANTWISE. Soyabean stem miner (Melanagromyza sojae). 2015. Available at: <http://www.plantwise.org/ knowledgebank/datasheet.aspx?dsid $=33003>$. Access on: 16 May 2018.

RATNASINGHAM, S.; HEBERT, P. D. N. Bold: the barcode of life data system (www.barcodinglife.org). Molecular Ecology Notes, v. 7, n. 3, p. 355-364, 2007.

SHEPARD, M. et al. Insects on grain legumes in northern Australia: a survey of potential pests and their enemies. Brisbane: University of Queensland Press, 1983.

STRAKHOVA, I. S. et al. The parasitoid complex (Hymenoptera, Eulophidae) of leaf miner flies (Diptera, Agromyzidae) in the middle Volga Basin. Entomological Review, v. 93, n. 7, p. 865-873, 2013.

TALEKAR, N. S. Characteristics of Melanagromyza sojae (Diptera: Agromyzidae) damage in soybean. Journal of Economic Entomology, v. 82, n. 2, p. 584-588, 1989.

THAPA, R. B. Redescription of Melanagromyza sojae (Zehntner) from India and Nepal. Nepalese Journal of Bioscience, v. 2, n. 1, p. 64-70, 2012.

WANG, J.; GAI, J. Mixed inheritance model for resistance to agromyzid bean fly (Melanagromyza sojae Zehntner) in soybean. Euphytica, v. 122, n. 1, p. 9-18, 2001. 